San Jose State University

SJSU ScholarWorks

10-7-2009

\title{
The Woman in the Zoot Suit: Gender, Nationalism, and the Cultural Politics of Memory
}

San Jose State University, Cultural Heritage Center

Follow this and additional works at: https://scholarworks.sjsu.edu/chc_flyers

\section{Recommended Citation}

San Jose State University, Cultural Heritage Center, "The Woman in the Zoot Suit: Gender, Nationalism, and the Cultural Politics of Memory" (2009). Cultural Heritage Center Event Flyers. 35.

https://scholarworks.sjsu.edu/chc_flyers/35

This Poster is brought to you for free and open access by the Africana, Asian American, Chicano, \& Native American Studies Center at SJSU ScholarWorks. It has been accepted for inclusion in Cultural Heritage Center Event Flyers by an authorized administrator of SJSU ScholarWorks. For more information, please contact scholarworks@sjsu.edu. 

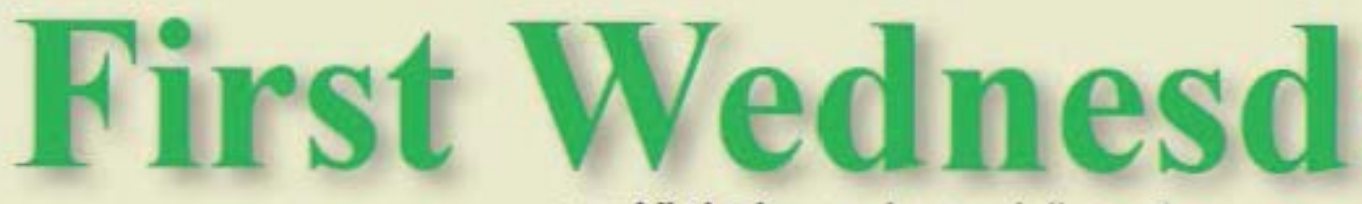

a public lecture and presentation series

sponsored by the King Library Special Collections

\section{Fall 2009 at 7:00 p.m.}

\section{THE WOMAN IN}

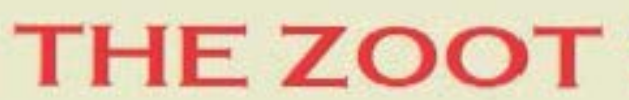

Gender, National, and the Cultural Politics of Memory

\section{Catherine Ramirez}

Professor of American Studies

University of California, Santa Cruz

author presentation \& book signing

\section{October 7,2009}

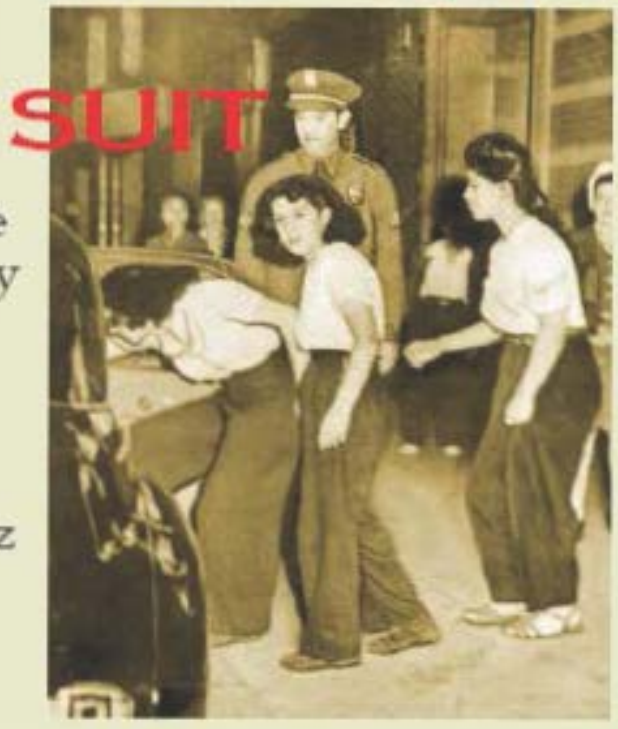

Sponsored by SJSU Special Collections \&

Cultural Heritage Center

Schiro Program Room 550, 5th Floor

Dr. Martin Luther King, Jx. Library San José State University 150 E. San Fernando Street

San José, CA 95112

Free admission: Limited Seating

For Parking information go to: http:/sjidountowuparking_com/free_parking,php ,

To arrange for an accommodation under the Americans with Disabiltities Act, call (408) 808-2130 TTY at least 48 hours in advance

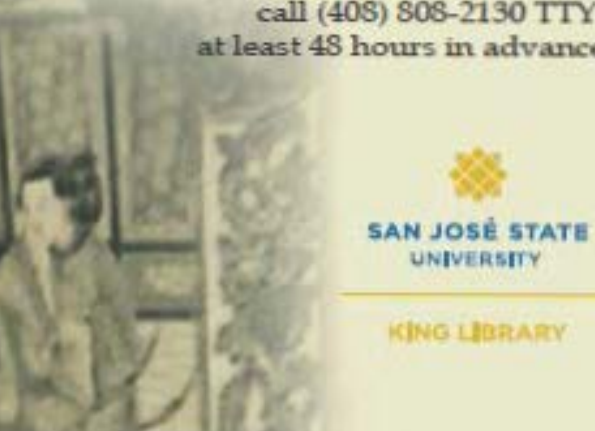

